\title{
The Effect of Corporate Strategy, Organizational Citizenship Behavior and Compensation on Organizational Culture and Company Performance (Study in Forestry SOE: Perum Perhutani)
}

\author{
Sangudi; Pribadiyono; Khuzaini \\ Indonesian College of Economics (STIESIA) Surabaya, Indonesia
}

http://dx.doi.org/10.18415/ijmmu.v8i9.2991

\begin{abstract}
This study aims to analyze and determine the effect of each variable on corporate strategy, organizational citizenship behavior and compensation on organizational culture and company performance in Forestry SOE: Perum Perhutani. The analytical instrument of this research is SEM (Structural Equation Modeling) through AMOS v.22 software which emphasized structural equation testing and model testing. The results of hypothesis testing from the model shows that: First, corporate strategy has a positive and significant effect on company performance. Second, organizational citizenship behavior has a positive and significant effect on company performance. Third, compensation has a positive and significant effect on company performance. Fourth, organizational culture has a positive and significant effect on company performance. Fifth, corporate strategy has a positive and significant effect on organizational culture. Sixth, organizational citizenship behavior has a positive and significant effect on organizational culture. Seventh, compensation has a positive and significant effect on organizational culture. In addition, the indirect effect test through the Sobel Test finds that organizational culture is able to intervene the effect of corporate strategy, organizational citizenship behavior and compensation on company performance.
\end{abstract}

Keywords: Corporate Strategy; Organizational Citizenship Behavior; Compensation; Organizational Culture; Company Performance; Resource-Based View (Rbv) Theory; Human Capital Theory

\section{Introduction}

Perum Perhutani is a State-Owned Enterprise (BUMN) which is engaged in forestry and is one of the SOEs whose existence still exists until this millennial era. However, since the 1998 reformation, Perum Perhutani has experienced complex problems. These challenges come from outside the company (cooptation of land by community members around the forest, illegal logging, forest shrinkage due to the need for public facilities such as toll roads, environmental issues such as the issue of a moratorium on logging in forests, etc.) the production of teak wood which has a very long life, on a hierarchical organizational culture, on a too-broad organizational structure, and a lack of transparency in managing operational integration between divisions and between business units). All of this has an effect on Perum Perhutani's business and high fixed costs.

These challenges then become a reference for management to determine the company's improvement strategy so that it can run better. Some of the steps that have been taken are streamlining the 
organizational structure that is able to reduce the number of employees which has an impact on employee salary efficiency (from 30,000 employees to 24,000 employees in 2010). The downsizing of employees is carried out by analyzing employee profiles and allowing employees who are nearing retirement to retire, so that there is no termination of employment and no recruitment of new employees (Zero Growth Strategy). In addition,management has also established BANSTRA (Strategic Agency and Corporate Transformation) which functions to oversee, build and supervise the transformation program so that it runs effectively. Another activity to increase the company's revenue is to implement a forest management strategy that does not only rely on teak trees, but also plant other forest plants. Some of these types of plants include mahogany, rosewood, resin, acacia, jabon, sengon, gmelina, rasamala, pulai and rubber trees.

In accordance with its duties in managing People-Planet-Profit, Perum Perhutani also provides social compensation to Forest Village Communities, commonly known as Forest Village Communities (MDH). The realization of the company's social activities is contained in the company's plan through the forest village community development program. Perum Perhutani's concern in providing compensation assistance to Forest Village Communities (MDH) continues to change according to government policies and community needs. Finally, it is called Community Forest Management (PHBM) which is the concept of sharing in tasks, responsibilities, roles and production results. The long journey of forest management with the community carried out by Perum Perhutani is presented in Figure 1 below.

DEVELOPMENT OF COMMUNITY PARTICIPATION IN FOREST MANAGEMENT IN JAVA ISLAND

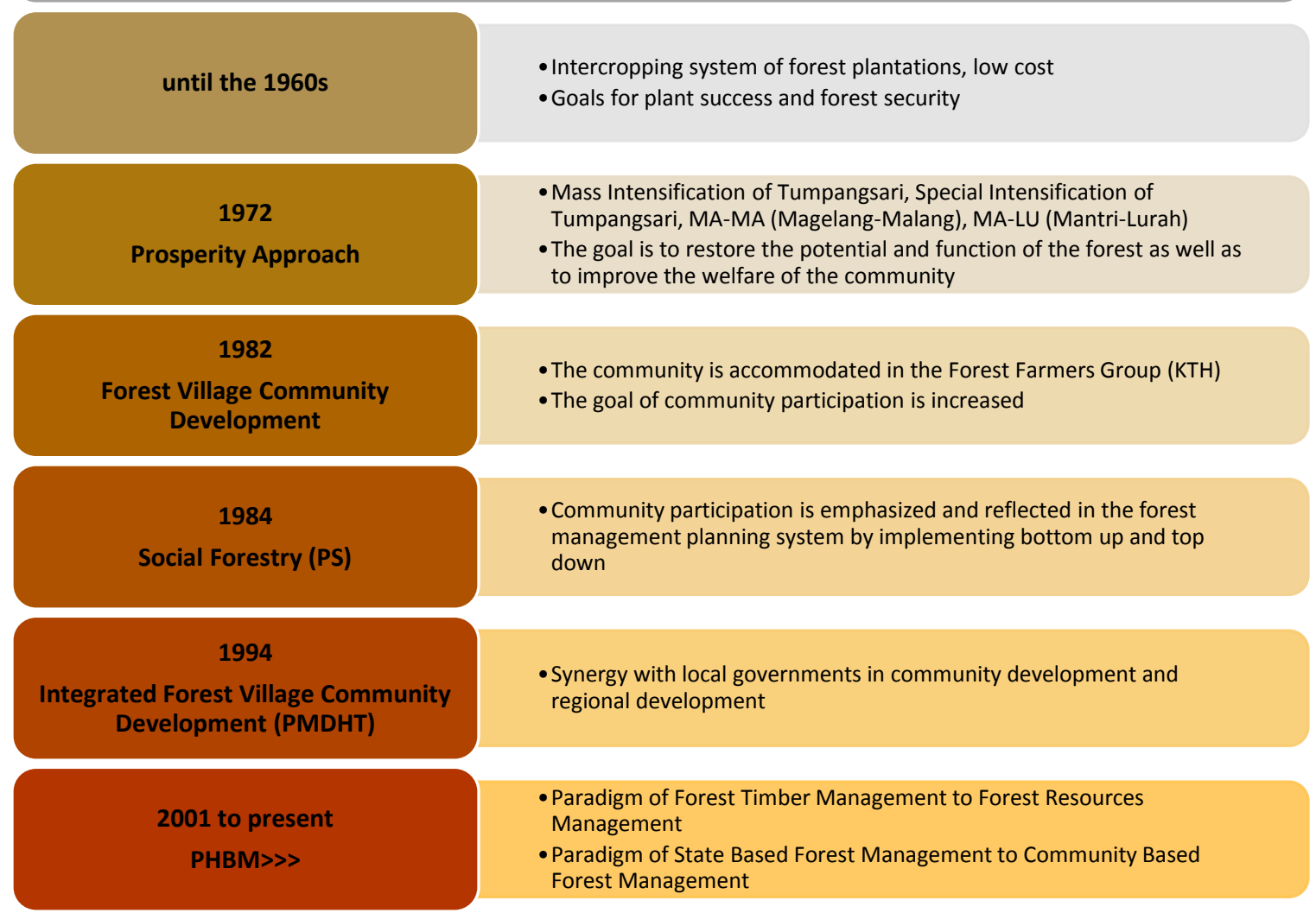

Figure 1. Community Forest Management by Perum Perhutani

(Source: PSDH Department of Perum Perhutani)

The research gaps that underlie this research are the following studies. Ehsan \& Kaleem (2012), through the results of their research, suggest that there is a positive and significant effect between corporate 
strategy on company performance. However, different results were found in the research results of Chathoth \& Olsen (2007) which showed that the company's strategy had no significant effect on company performance. This is the first gap in this study because there are still inconsistencies between the role of corporate strategy on company performance. For this reason, this study will further examine the role of corporate strategy on company performance.

According to (Chun et al., 2015; Kizilos et al., 2013; Kolade \& Ogunnaike, 2014; Martínez \& Scott Tindale, 2015; Purnama, 2013; Sadeghi et al., 2016; Shahin et al., 2014), Organizational Citizenship Behavior (OCB) has a positive and significant effect on company performance. These results are different from research conducted by Hanzaee \& Mirvaisi (2013) which shows that organizational citizenship behavior (OCB) has no effect on employee performance. This is the second gap in this study because there are still inconsistencies between the role of Organizational Citizenship Behavior (OCB) on company performance. For this reason, this study will further examine the role of Organizational Citizenship Behavior (OCB) on company performance.

According to research by (Amin et al., 2014; Banker et al., 2013; Hassan, 2016; Tomczyk et al., 2013), compensation has a positive and significant effect on company performance. However, different findings are shown by the research of Chen \& Jermias (2014) that compensation has a negative effect on company performance. This is the third gap in this research because it turns out that there are still inconsistencies between the role of compensation and the company's performance. For this reason, this study will further examine the role of compensation on company performance.

Research by (Awadh \& Alyahya, 2013; Jacobs et al., 2013; O’Reilly III et al., 2014; Tseng, 2010; Uzkurt et al., 2012) shows that organizational culture has a significant effect on positive and significant to the company's performance. However, different findings were obtained from the research of Lee \& Kim (2017) that organizational culture has a negative but significant effect on company performance. This is the fourth gap in this research because it turns out that there are still inconsistencies between the role of organizational culture on company performance. For this reason, this study seeks to further examine the role of organizational culture on company performance.

Research conducted by Garri et al., (2013) shows that organizational strategy has a positive and significant relationship with organizational culture. Another opinion was expressed by Tasgit et al., (2017) who found that defensive strategies were negatively affected by adhocracy culture. On the other hand, the characteristics of defensive strategies, compared to those of adhocracy and market cultures, make it easier to understand why the relationship is negative. This is the fifth gap in this research because it turns out that there are still inconsistencies between the role of organizational strategy and organizational culture. For this reason, this study seeks to further examine the role of organizational strategy on organizational culture.

The results of research by Muhtasom et al., (2017) show that Organizational Citizenship Behavior (OCB) has a positive and significant effect on organizational culture. These results are supported by research by Badawy et al., (2017) which shows that organizational culture and organizational citizenship behavior have a positive and significant correlation. Research conducted by Pashib et al., (2015) on employees at universities has different findings that there is a weak relationship between organizational culture and organizational citizenship behavior in the study population. This is the sixth gap of research because it turns out that there are still inconsistencies between the role of organizational citizenship behavior and organizational culture. For this reason, this study seeks to further examine the role of organizational citizenship behavior on organizational culture.

The compensation system is also known to have a significant effect on determining organizational culture (Li \& Roloff, 2007). Madhani (2014) adds through the results of his research that the compensation system that is designed, developed, communicated and managed, can positively or negatively affect

The Effect of Corporate Strategy, Organizational Citizenship Behavior and Compensation on Organizational Culture and Company Performance (Study in Forestry SOE: Perum Perhutani) 
organizational culture. Given that individual reward plans are often criticized for having a negative effect on organizational culture (Pfeffer, 1998), the research design applied to this study adds a new perspective to the question of the relative attractiveness of individual and collective rewards. This is the seventh gap of research because it turns out that there are still inconsistencies between the role of compensation and organizational culture. For this reason, this study seeks to further examine the role of compensation on organizational culture.

Based on the Garp Research study above, there are still differences in the results that create gaps in both measuring organizational culture and company performance. Therefore, the present study will try to make the research renewable by analyzing the effect between these variables.

\section{Research Method}

\section{Research Design}

In accordance with the objective and significance of the research, this research design uses a causal research design or a quantitative type of causality. It is a study that aims to analyze the relationships between one variable and another (causal relationship) through hypothesis testing. According to Sugiyono (2017), causal research design is to examine the "cause and effect" relationship between exogenous (independent) variables and endogenous variables (dependent variable).

The main factor consists of several latent variables, then each variable consists of several indicators to be measured. This study applies a quantitative statistical approach using Structural Equation Modeling (SEM) analysis, a statistical technique that analyzes causal relationships between latent variables (unobserved variables). SEM analysis is basically a combination of factor analysis, correlation and regression analysis and path analysis.

\section{Population and Sample}

The research population is Perum Perhutani employees who occupy strategic positions. The selection was based on consideration of the knowledge of the focus of research related to corporate strategy, Organizational Citizenship Behavior (OCB), compensation, corporate culture, and company performance that not all employees understand the terms, definitions and philosophy of the related variables. The composition of the study population is presented in Table 1 below:

Table 1. Number of Strategic Officials and DPP Managers of Perum Perhutani Employee Unions in 2019

\begin{tabular}{|c|c|c|c|c|c|c|}
\hline & $\begin{array}{l}\text { Head of } \\
\text { Division and } \\
\text { equivalent }\end{array}$ & $\begin{array}{l}\text { Head of } \\
\text { Bureau and } \\
\text { equivalent }\end{array}$ & $\begin{array}{l}\text { Administration/ } \\
\text { General } \\
\text { Manager }\end{array}$ & $\begin{array}{l}\text { Manager/ } \\
\text { Section } \\
\text { Head }\end{array}$ & $\begin{array}{l}\text { DPP } \\
\text { Sekar/SP2P } \\
\text { Management }\end{array}$ & Total \\
\hline Head Office & 22 & 32 & 36 & 145 & 16 & 251 \\
\hline $\begin{array}{l}\text { Central Java } \\
\text { Region }\end{array}$ & 3 & 15 & 21 & 149 & - & 188 \\
\hline $\begin{array}{ll}\text { East } & \text { Java } \\
\text { Region } & \end{array}$ & 3 & 17 & 26 & 177 & - & 223 \\
\hline $\begin{array}{l}\text { West Java- } \\
\text { Banten Region }\end{array}$ & 3 & 7 & 21 & 127 & - & 158 \\
\hline Total & 31 & 71 & 104 & 598 & 16 & 820 \\
\hline
\end{tabular}

Source: Directorate of Human Resources and General Affairs of Perum Perhutani 
In this study, the sample was determined through proportionate stratified random sampling, a technique of taking samples from a proportionally stratified non-homogeneous population. The number of samples from each stratum according to the proportion of the population is 83 respondents in the head office, 62 respondents in the Central Java Region, 73 respondents in the East Java Regional area and 51 respondents in the West Java and Banten Regional areas. To anticipate various possibilities, the questionnaires distributed were added by approximately 15\% (41 respondents) expecting that 269 questionnaires were returned.

\section{Research Instrument Testing}

The research instrument was tested using validity and reliability tests. The minimum requirement for the validity of an instrument item is if the Pearson product moment index value ( $r$ ) which measures the closeness of the correlation between the question scores and the total scores of the observed variables is > 0.3 (Sugiyono, 2017). Reliability is the degree to which a measure creates the same response over time and across situations. An instrument is said to be reliable if the measurement results from the instrument are stable and consistent with the statistical test parameters of Cronbach's alpha $(\alpha)$ above 0.7 (Silalahi, 2012).

\section{Data Analysis Technique}

After collecting the data, all the data collected was then processed and analyzed by the researcher. Questionnaire questions addressed to individual elected officials (as respondents) will be analyzed to describe the condition of Perum Perhutani (organization). This is in line with the goal of statistics Sudaryono (2019) that statistical techniques can be used to analyze sample data and the results are applied to the population (organizational strategic officials). Data analysis in this study used descriptive statistics and inferential statistics.

Inferential statistics (often also called inductive statistics or probability statistics) are statistical techniques used to analyze sample data and the results are applied to the population. In this study, the answers to questions or statements of parameter items/questions in the questionnaire will be recorded in the frequency tabulation and then will be analyzed using the inferential SEM (structural equation modeling) technique.

Hypothesis testing is carried out to analyze and draw conclusions on the problems being studied. This test is intended to determine the causality relationship as stated in the hypothesis that has been proposed in this study. The steps for testing the hypothesis in this study can be seen from the results of the significance value of the estimated standardized loading parameter, where Ho is rejected if the probability value is $<0.05$ (Ferdinand, 2014).

In this study, the Sobel test will also be carried out by testing the strength of the indirect effect of exogenous variables (Corporate Strategy, Organizational Citizenship Behavior and Compensation) to endogenous variables (Company Performance) through intervening variables (Organizational Culture). The standard error of indirect effect is calculated by the formula:

$s a b=\sqrt{b^{2} s a^{2}+a^{2} s b^{2}+s a^{2} s b^{2}}$

Description:

$\mathrm{s} \quad=$ standard error

$\mathrm{a}, \mathrm{b}, \mathrm{c} \quad=$ regression coefficient 
Testing the significance of the indirect effect using the following formula:

$t=\frac{a b}{s a b}$

The p-value results were compared with 0.05 . If the p-value is smaller than 0.05 , it is concluded that there is an intervening effect. This Sobel test can also be calculated through the Online Sobel Calculator (http://quantpsy.org/sobel/sobel.htm).

\section{Research Results}

The analysis technique in this research is Structural Equation Modeling (SEM). SEM is a powerful statistical technique in establishing measurement models and structural models. SEM is also based on a causal relationship where changes in one variable have an impact on changes in other variables. So the use of SEM is in accordance with the purpose of this study to prove and analyze the effect of exogenous variables (corporate strategy, organizational citizenship behavior and compensation) on endogenous variables (organizational culture and company performance).

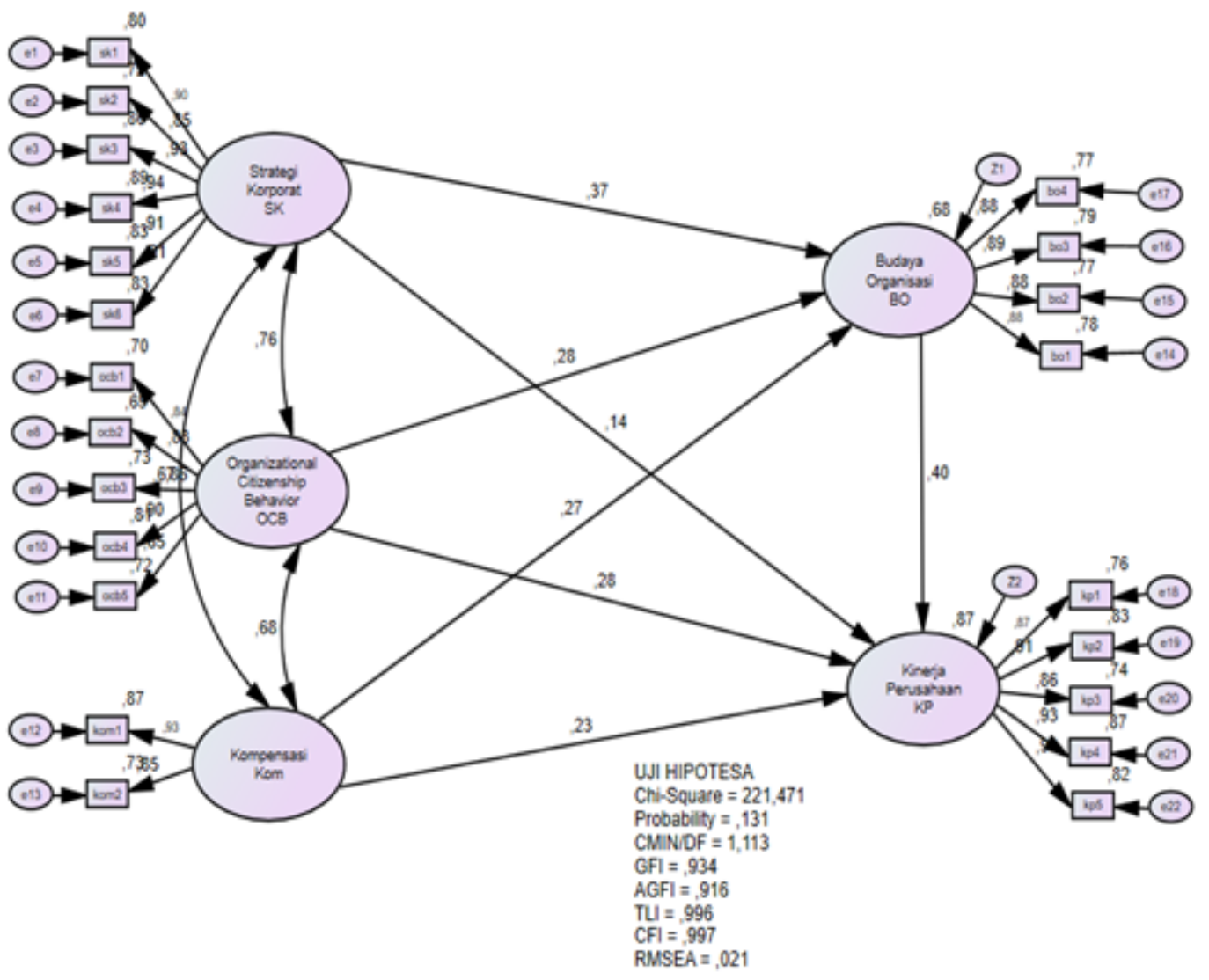

Figure 2. Full SEM Model Analysis

Based on the output of the full SEM model analysis in Figure 2, it shows the relationship between exogenous constructs and between exogenous constructs and endogenous constructs. 


\section{a. Evaluation of the Goodness of Fit Criteria}

The goodness of fit of the model test shows that the constructs in the research model fit the research data.

The summary of the results of the goodness of fit test can be seen in Table 2:

Table 2. Summary of Test Results on the Goodness of Fit of the Model

\begin{tabular}{llll}
\hline Goodness of Fit Index & Analysis Results & Cut of Value & $\begin{array}{l}\text { Model } \\
\text { Evaluation }\end{array}$ \\
\hline X $^{2}$ Chi-Square & 221.471 & $<325.880$ & Good \\
Probability & 0.131 & $>0.05$ & Good \\
CMIN/DF & 1.113 & $<2.00$ & Good \\
GFI & 0.934 & $>0.90$ & Good \\
AGFI & 0.916 & $>0.90$ & Good \\
TLI & 0.996 & $>0.95$ & Good \\
CFI & 0.997 & $>0.95$ & Good \\
RMSEA & 0.021 & $<0.08$ & Good \\
\hline
\end{tabular}

Source: Appendix 7

Referring to the data in Table 2, the results of each test can then be explained as follows:

1. $\mathrm{X}^{2}$ - Chi-Square Statistics

$\mathrm{X}^{2}$ - chi-square is 221,471 which is smaller than the value of the chi-square table with an error rate of $1 \%$ and the number of samples is 269 , which is 325,880 which indicates that the test model is accepted in the good category.

\section{Probability}

The probability value is 0.131 , which is much greater than the cut-of value, which is 0.05 . This value indicates that there is a significant difference between the covariance matrix of the research data and the estimated covariance matrix, so that the model is accepted in the good category.

\section{The Minimum Sample of Discrepancy Function Divide with Degree of Freedom (CMIN/DF)}

The CMIN/DF value of the full SEM model is 1.113 which is smaller than the cut-of value of 2.00 which indicates an acceptable fit where the model is accepted in a good category.

\section{Goodness-of-Fit Index (GFI)}

The GFI value is 0.934 which is greater than the cut of value which is 0.90 which indicates that the fitness level of the weighted proportion of the variance of the sample covariance matrix described by the population matrix is accepted in the good category.

\section{Adjusted Goodness of Fit Index (AGFI)}

The value of the AGFI full SEM model is 0.916 which is greater than the cut-of value of 0.90 which indicates that the fitness level between the weighted proportions of the variance in the sample matrix described by the population matrix is accepted in the good category. 
6. Tucker Lewis Index (TLI)

The results of the goodness of fit model test show the TLI value $=0.996$, which is greater than the cut of value, which is 0.95 . It shows that the fitness level of the incremental index that compares the model with the baseline model is accepted in the good category.

\section{Comparative Fit Index (CFI)}

The CFI value in this research model is 0.997 which is also greater than the cut of value which is 0.95. This value indicates that the suitability of the index that compares a model to the baseline model is accepted in the good category.

\section{The Root Mean Square Error of Approximation (RMSEA)}

The RMSEA value is 0.021 which is smaller than the cut of value of 0.08 which indicates the acceptance index of the close fit model based on the degree of freedom feels in the good category.

\section{b. Validity, Reliability and Variance Extract Tests}

Based on the results of the validity test in Table 3, the loading factor value for all indicators for each variable is greater than 0.500 . Thus, all indicators are proven valid and can be used as a data collection tool in this study.

Table 3. Research Variable Validity Test Results

\begin{tabular}{llll}
\hline Variables & Indicators & Loading Factor & Description \\
\hline Corporate_Strategy (SK) & $\mathrm{SK}_{1}$ & 0.893 & Valid \\
& $\mathrm{SK}_{2}$ & 0.847 & Valid \\
& $\mathrm{SK}_{3}$ & 0.930 & Valid \\
& $\mathrm{SK}_{4}$ & 0.945 & Valid \\
& $\mathrm{SK}_{5}$ & 0.907 & Valid \\
& $\mathrm{SK}_{6}$ & 0.911 & Valid \\
\hline Organizational_Citizenship_Behavior & $\mathrm{OCB}_{1}$ & 0.829 & Valid \\
(OCB) & $\mathrm{OCB}_{2}$ & 0.930 & Valid \\
& $\mathrm{OCB}_{3}$ & 0.899 & Valid \\
& $\mathrm{OCB}_{4}$ & 0.858 & Valid \\
& $\mathrm{OCB}_{5}$ & 0.858 & Valid \\
\hline Compensation (Kom) & $\mathrm{Kom}_{1}$ & 0.854 & Valid \\
& $\mathrm{Kom}_{2}$ & 0.931 & Valid \\
\hline Organizational_Culture (BO) & $\mathrm{BO}_{1}$ & 0.878 & Valid \\
& $\mathrm{BO}_{2}$ & 0.877 & Valid \\
& $\mathrm{BO}_{3}$ & 0.869 & Valid \\
& $\mathrm{BO}_{4}$ & 0.904 & Valid \\
\hline Company_Performance (KP) & $\mathrm{KP}_{1}$ & 0.871 & Valid \\
& $\mathrm{KP}_{2}$ & 0.864 & Valid \\
& $\mathrm{KP}_{3}$ & 0.911 & Valid \\
& $\mathrm{KP}_{4}$ & 0.936 & Valid \\
& $\mathrm{KP}_{5}$ & 0.905 & Valid \\
\hline
\end{tabular}

Based on the calculation results in Table 3, the variance extract values for the indicators of corporate strategy variables, organizational citizenship behavior, compensation, organizational culture and 
company performance variables are each greater than 0.500 . Thus, the constructs of each variable in this study were declared valid and suitable to be used to test the causal relationship in this study.

Table 4. Research Variable Reliability Test Results

\begin{tabular}{llll}
\hline Variables & $\begin{array}{l}\text { Composite } \\
\text { Reliability }\end{array}$ & $\begin{array}{l}\text { Variance } \\
\text { (AVE) }\end{array}$ & $\begin{array}{l}\text { Extracted } \\
\text { Discriminant } \\
\text { Validity }\end{array}$ \\
\hline Corporate_Strategy (SK) & 0.965 & 0.821 & 0.906 \\
Organizational_Citizenship_Behavior (OCB) & 0.931 & 0.731 & 0.855 \\
Compensation (Kom) & 0.887 & 0.798 & 0.893 \\
Organizational_Culture (BO) & 0.961 & 0.777 & 0.881 \\
Company_Performance (KP) & 0.954 & 0.806 & 0.898 \\
\hline
\end{tabular}

Referring to the calculation results of the reliability test in Table 4, the loading factor coefficient of each variable is greater than 0.500 . Thus, the construct of each variable is declared reliable and can be used as a data collection instrument.

\section{c. Hypothesis Testing Results}

The research hypothesis testing was carried out based on the results of the analysis of the causal relationship between the research constructs as can be seen in Figure 2 full SEM analysis with the description in Table 5 below.

Table 5. Results of Research Hypothesis Testing

\begin{tabular}{|c|c|c|c|c|c|}
\hline \multirow[b]{2}{*}{ No. } & \multirow[b]{2}{*}{ Variables } & \multicolumn{3}{|c|}{ Standardized Coefficient Value } & \multirow[b]{2}{*}{ Decision } \\
\hline & & Direct Effect & CR & $\begin{array}{l}\mathbf{p} \\
\text { value }\end{array}$ & \\
\hline$\overline{\mathrm{H}_{1}}$ & $\mathrm{SK} \rightarrow \mathrm{KP}$ & 0,14 & 2,656 & 0,008 & (+) significant \\
\hline $\mathrm{H}_{2}$ & $\mathrm{OCB} \rightarrow \mathrm{KP}$ & 0,28 & 5,067 & 0,000 & (+) significant \\
\hline $\mathrm{H}_{3}$ & $\mathrm{KOM} \rightarrow \mathrm{KP}$ & 0,23 & 4,581 & 0,000 & (+) significant \\
\hline $\mathrm{H}_{4}$ & $\mathrm{BO} \rightarrow \mathrm{KP}$ & 0,40 & 6,930 & 0,000 & (+) significant \\
\hline $\mathrm{H}_{5}$ & $\mathrm{SK} \rightarrow \mathrm{BO}$ & 0,37 & 5,244 & 0,000 & (+) significant \\
\hline $\mathrm{H}_{6}$ & $\mathrm{OCB} \rightarrow \mathrm{BO}$ & 0,28 & 3,769 & 0,000 & $(+)$ significant \\
\hline $\mathrm{H}_{7}$ & $\mathrm{KOM} \rightarrow \mathrm{BO}$ & 0,27 & 4,154 & 0,000 & (+) significant \\
\hline
\end{tabular}

1. The value of the standardized regression weight coefficient between Corporate Strategy (SK) and Company Performance (KP) is 0.139 with a probability of 0.008 ( $\mathrm{p}<0.05)$ Corporate Strategy variable has a positive and significant effect on the Company Performance variable, which means that the first hypothesis can be accepted.

2. The value of the standardized regression weight coefficient between Organizational Citizenship Behavior (OCB) and Company Performance (KP) is 0.276 with a probability of 0.000 or $p<0.05$. This shows that the variable organizational citizenship behavior has a positive and significant effect on the company's performance variable, which means that the second hypothesis can be accepted.

3. The value of the standardized regression weight coefficient between Compensation (Kom) and Company Performance (KP) is 0.226 with a probability of 0.005 or $\mathrm{p}<0.05$. This shows that the Compensation variable has a positive and significant effect on the Company Performance variable, which means that the third hypothesis can be accepted.

4. The standardized regression weight coefficient value between Organizational Culture (BO) and Company Performance (KP) is 0.399 with a probability of 0.000 or $\mathrm{p}<0.05$. This shows that the organizational culture variable has a positive and significant effect on the company's performance variable, which means that the fourth hypothesis can be accepted. 
5. The standardized regression weight coefficient value between Corporate Strategy (SK) and Organizational Culture (BO) is 0.370 with a probability of 0.000 or $\mathrm{p}<0.05$. This shows that the corporate strategy variable has a positive and significant effect on the organizational culture variable, which means that the fifth hypothesis can be accepted.

6. The value of the standardized regression weight coefficient between Organizational Citizenship Behavior (OCB) and Organizational Culture (BO) is 0.275 with a probability of 0.000 or $p<0.05$. This shows that organizational citizenship behavior has a positive and significant effect on organizational culture variables, which means that the sixth hypothesis can be accepted.

7. The value of the standardized regression weight coefficient between Compensation (Kom) and Organizational Culture (BO) is 0.271 with a probability of 0.000 or $\mathrm{p}<0.05$. This shows that the compensation variable has a positive and significant effect on the organizational culture variable, which means that the seventh hypothesis can be accepted.

\section{d. Evaluation of Indirect Effect Using the Sobel Test}

Sobel test is a test to determine whether the relationship through an intervening variable is able to function as a mediator in the relationship. The results of this study as Table 6 show the magnitude of the indirect effect between variables with the Organizational Culture (BO) variable as the intervening variable.

Table 6. Results of Testing the Indirect Effect of the Research Hypothesis

\begin{tabular}{lllllll}
\hline \multirow{2}{*}{ Path } & $\mathrm{a}$ & $\mathrm{b}$ & $\mathrm{SEa}$ & $\mathrm{SEb}$ & \multirow{2}{*}{ P Value } & $\mathrm{t}$ \\
& $\mathrm{SK} \rightarrow \mathrm{BO}_{1}$ & $\mathrm{BO}_{1} \rightarrow \mathrm{KP}_{2}$ & $\mathrm{SK} \rightarrow \mathrm{BO}_{1}$ & $\mathrm{BO}_{1} \rightarrow \mathrm{KP}_{2}$ & & \\
\hline $\mathrm{SK}>\mathrm{BO}->\mathrm{KP}$ & 0.370 & 0.399 & 0.064 & 0.066 & 0.0000 & 4.178 \\
\hline \multirow{2}{*}{ Path } & $\mathrm{a}$ & $\mathrm{b}$ & $\mathrm{SEa}$ & $\mathrm{SEb}$ & \multirow{2}{*}{ P Value } & $\mathrm{t}$ \\
\hline OCB->BO->KP & 0.275 & 0.399 & 0.078 & 0.066 & 0.0000 & 3.046 \\
\hline \multirow{2}{*}{ Path } & $\mathrm{a}$ & $\mathrm{b}$ & $\mathrm{SEa}$ & $\mathrm{SEb}$ & \multirow{2}{*}{ P Value } & \multirow{2}{*}{$\mathrm{t}$} \\
\hline KOM->BO->KP & 0.271 & 0.399 & 0.054 & 0.066 & 0.0000 & 3.861 \\
\hline
\end{tabular}

The conclusion from the results of the Sobel Test shows that all independent variables, namely SK, OCB and Kom have an effect on KP through BO. This means that the better Corporate Strategy of Perum Perhutani will improve the Company's Performance if the Organizational Culture is also improved. Likewise, the better Organizational Citizenship Behavior of Perum Perhutani will improve the Company's Performance in line with the better Organizational Culture. In addition, the provision of better compensation from Perum Perhutani to all employees will further improve the Company's performance in line with the better Organizational Culture implemented by Perum Perhutani.

\section{Competing Model Evaluation}

The last step in measuring the model using SEM is to compare the proposed model with a comparison model (Hair et al., 2017). Alternative models can be built by adding relationships or reducing relationships between variables (Zhou et al., 2019). For this reason, an alternative model is built by reducing the direct relationship between variables that are proven to have the lowest effect in the main model proposed, namely the relationship between corporate strategy and company performance. The results of the comparison of the proposed model with the comparison model can be seen in Table 6 below. 
Table 6. Summary of Estimated Model and Competing Model Fit Index

\begin{tabular}{lll}
\hline Model Fit Index & Estimated Model & Competing Model \\
\hline$X^{2}$ Chi-Square & 221.471 & 227.999 \\
Probability & 0.131 & 0.085 \\
CMIN/DF & 1.113 & 1.140 \\
GFI & 0.934 & 0.932 \\
AGFI & 0.916 & 0.914 \\
TLI & 0.996 & 0.995 \\
CFI & 0.997 & 0.996 \\
RMSEA & 0.021 & 0.023 \\
\hline
\end{tabular}

Based on the calculation results above, the Chi Square value and the $\mathrm{X}^{2}$ Chi-Square and CMIN/DF values of the comparison model are greater than the proposed model. Meanwhile, the GFI value of the comparison model shows a smaller value than the GFI value in the proposed model. Based on the results of the above analysis, it is concluded that the proposed model is better than the comparison model.

\section{Discussion}

\section{Effect of Corporate Strategy on Company Performance}

Hypothesis 1 which states that corporate strategy has an effect on company performance can be accepted (proven). Good and bad company performance is affected by corporate strategy. The better the corporate strategy planned and implemented, the better the company's performance of Perum Perhutani.

The results of this study are in accordance with the Theory of Corporate Strategy proposed by Ansoff (1965) that the indicators studied and measured all show conformity with those prevailing in Perum Perhutani as the research company. For Perum Perhutani, these findings are very meaningful as an evaluation material. So far, Perum Perhutani has been under the spotlight by external parties because the configuration displayed is deemed not in accordance with consumer needs. The results of this study indicate that configuration $\left(\mathrm{SK}_{.3}\right)$ has the smallest effect compared to other indicators. The biggest effect actually refers to the Management System (SK.5) especially on the aspect of the effectiveness of the performance evaluation management system control $\left(\mathrm{SK}_{5.2}\right)$ and the effectiveness of the cost control system $\left(\mathrm{SK}_{5.1}\right)$ which is followed by Leadership and Style ( $\mathrm{SK}_{.6}$ ), especially on the aspect of the code of ethics. employees in upholding moral/akhlaq values ( $\left.\mathrm{SK}_{.6 .2}\right)$.

These results can be compared with research conducted by de Villiers-Scheepers (2012) which states that a supportive organizational climate is a very important capability for companies. Meanwhile Turro Sol (2015) shows that it is important to create the right regulatory framework for a corporation. This is also in line with the RBV Grand Theory which states that RBV pays attention to how companies maintain competitive advantage with competitors through superior corporate strategies.

\section{Effect of Organizational Citizenship Behavior (OCB) on Company Performance.}

Hypothesis 2 states that organizational citizenship behavior affects the company's performance is acceptable. It means that organizational citizenship behavior in Perum Perhutani affects the company's performance. The better the OCB character in the soul of every Perum Perhutani employee, the better the performance of the Perum Perhutani company.

The results of this study are in line with the researcher's estimate that the very strong spirit of the perum perhutani people reflects the strong value of organizational citizenship behavior. This condition is 
in line with the theory of organizational citizenship behavior according to Organ et al (2006) which defines organizational citizenship behavior as voluntary individual behavior to achieve organizational goals. For Perum Perhutani, this result can indicate that most of Perhutani's employees are very concerned about the future of the company. Employees work not only in accordance with what is charged by the company, but also have a sense of volunteerism.

For Perum Perhutani, whose business is related to social and environmental issues, this condition is encouraging, considering that Perhutani employees have a background as foresters who are formed with a very strong corporal spirit or formed with very strong organizational citizenship behavior which adheres to the Javanese philosophy. "handarbeni company" is a sense of belonging to the Perum Perhutani company as part of his life. This means that there is a strengthening of the values and paradigms of the foresters of Perum Perhutani which need to be continuously improved and the factors sought to continue to foster the spirit of corps of Perum Perhutani employees. Referring to the theory of human capital, organizational citizenship behavior that applies in Perum Perhutani has fulfilled the 6 (six) elements required by Hasbullah (2006) which include participation in groups/networks, altruism spirit to help each other among colleagues in the team, mutual trust between members team, has agreed social norms, has guided customary values and is proactive in solving all problems.

\section{Effect of Compensation on Company Performance}

Good compensation will improve company performance. The greater or better the compensation from the company to employees, the better the organizational performance. Thus, Hypothesis 3 which states that compensation has an effect on company performance can be accepted (proven).

The results of this study are in line with the research of Chen \& Jermias (2014) which state that a competitive company strategy must be supported by an effective compensation system. Compensation based on performance is considered capable of improving employee performance to achieve the target in realizing the bonuses they will get. Thus, compensation has a positive and significant effect on the company's performance. This is also in line with RBV's parent theory that compensation is very relevant as a basis for performance development based on Human Capital theory where each individual is required to develop their talents and competencies.

\section{Effect of Organizational Culture on Company Performance}

The better the organizational culture, the better the company's performance. Thus, Hypothesis 4 which states that organizational culture has an effect on company performance can be accepted (proven). The results of this study are in line with research by Awadh \& Alyahya (2013) where company performance has a strong impact on organizational culture. A strong organizational culture is considered capable of leading to increased productivity. In an organization, a strong culture enables effective and efficient management. Referring to Denison's Organizational Culture Theory, the results of the study show that the indicators of Involvement (BO3) which include employee empowerment programs as a forum for information that can be accessed by all employees, the creation of company work situations in facilitating the formation of a solid work team and the company's HR capability development program in facilitating educational training, has a considerable effect after the Mission indicator. Based on these results, the involvement indicator should be the main concern for Perum Perhutani management in addition to the Mission indicator which includes the description of the company's vision in accordance with the company's long-term strategy, clarity of company goals and objectives and Work Guidelines prepared by the company as guidance for employees in carrying out their work. 


\section{Effect of Corporate Strategy on Organizational Culture}

Through the implementation of a good corporate strategy, it is certain that it will improve and strengthen the organizational culture. Thus, Hypothesis 5 which states that corporate strategy has an effect on organizational culture can be accepted (proven).

The results of this study are in line with research by Garri et al (2013) who found that the applied corporate strategy has a correlation that reflects a positive organizational culture. The implementation of a customer-centered strategy is basically the main expression of corporate culture, because customer values are often embedded in the company's principles. This is also corroborated by the research of Tasgit et al., (2017) who found that corporate strategy has an effect on organizational culture.

\section{Effect of Organizational Citizenship Behavior (OCB) on Organizational Culture}

Through good Organizational Citizenship Behavior, it is certain that it will improve a good Organizational Culture as well. Thus, Hypothesis 6 which states that Organizational Citizenship Behavior (OCB) has an effect on organizational culture can be accepted (proven). The results of this study are in line with the results of research by Muhtasom et al., (2017) that organizational citizenship behavior has a positive and significant effect on organizational culture. Muhtasom's research is in line with the research of Pashib et al (2015) which found that OCB has a correlation with organizational culture. It is also supported by research by Badawy et al., (2017) which shows that organizational culture and organizational citizenship behavior have a positive and significant correlation.

\section{Effect of Compensation on Organizational Culture}

The better the compensation the company provides, the better the effect on organizational culture. Thus, Hypothesis 7 which states that compensation has an effect on organizational culture can be accepted (proven). Overall, the results of this study show conformity with the pyramid theory designed at the beginning of the study. The RBV Grand Theory according to Wernerfelt (1984), which states about how companies actually operate in creating competitiveness, becomes an umbrella for all theories supporting research variables which include corporate strategy, OCB, compensation, organizational culture and company performance. They rely on the human capital theory that human resources are an important asset for the success of organizational competitiveness, referring to knowledge, skills and abilities.

The results of this study are also very interesting to observe because the three variables of Corporate Strategy, OCB and Compensation have a significant positive effect on Denison's version of organizational culture, namely adaptability, mission, involvement and consistency. In other words, it means that it is in line with the INTIKU culture (Integrity, innovative, customer focus and excellence) prevailing at Perum Perhutani and the moral culture proclaimed by the Minister of SOEs, Erick Thohir.

\section{Indirect Effect Testing through Sobel Test}

The results of Sobel's analysis show that corporate strategy has a significant effect on company performance through organizational culture, with a p-value of $0.0000<0.05$ (95\% confidence level). Organizational citizenship behavior has a significant effect on company performance through organizational culture, with a p-value of $0.0000<0.05$ (95\% confidence level).

Meanwhile, compensation (Kom) has a significant effect on company performance through organizational culture with a p-value of $0.0000<0.05$ (95\% confidence level). 
Thus, it can be simplified that corporate strategy is significantly positively related to the overall company performance variable through organizational culture. This means that if the implementation of corporate strategy is getting better, the organizational culture will be more positive so that the company's performance will increase. Good and bad company performance is also influenced by organizational citizenship behavior. The better the organizational citizenship behavior applied, the better the company's performance through a good organizational culture. Organizational citizenship behavior has a significant positive relationship with overall company performance variables through organizational culture. Compensation will also improve company performance. The greater or better the compensation given by the company to employees, it can make the organizational culture at Perum Perhutani better and will have an impact on improving company performance. The following is a model chart that states the relationship of corporate strategy, OCB and compensation to organizational culture and company performance. It can be illustrated as the following Figure:

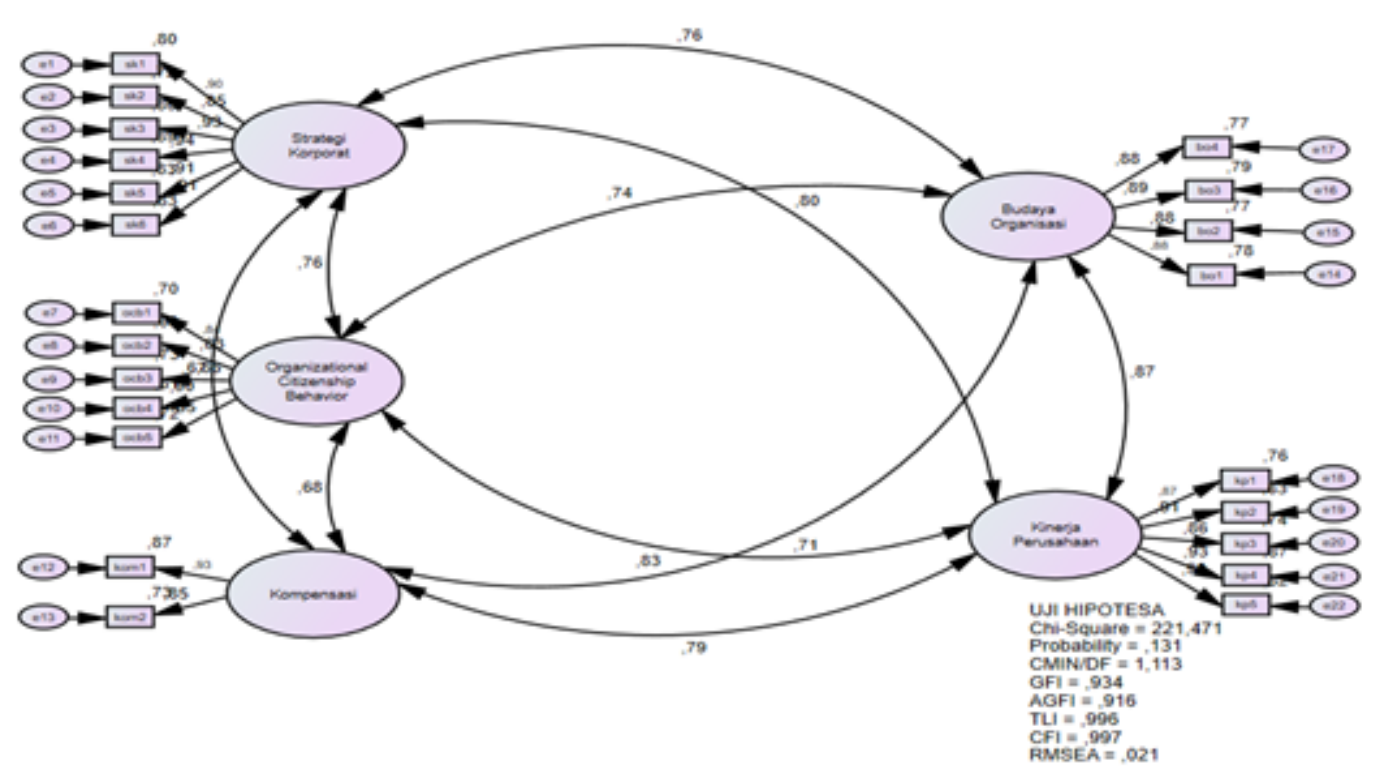

Figure 3. Correlation Between Variables

\section{Conclusion}

Corporate strategy has a positive and significant effect on company performance. If the company's strategy which includes corporate concept, configuration, coordination, organizational design, management system and leadership and style is implemented properly, it will improve company performance. Organizational citizenship behavior has a positive and significant effect on company performance. In other words, if organizational citizenship behavior which includes altruism conscientiousness, civic virtue, sportsmanship and courtesy is improved, it will improve company performance.

Compensation has a positive and significant effect on company performance. If compensation is increased, which includes intrinsic compensation and extrinsic compensation, it will improve the company's performance. Organizational culture has a positive and significant effect on company performance. If the organizational culture that includes adaptability, mission, involvement, and consistency is implemented properly, it will improve the company's performance. Corporate strategy has a positive and significant effect on organizational culture. If the company's strategy which includes corporate concept, configuration, coordination, organizational design, management system and leadership and style is implemented properly, it will improve organizational culture. 
Organizational citizenship behavior has a positive and significant effect on organizational culture. If organizational citizenship behavior which includes altruism, conscientiousness, civic virtue, sportsmanship and courtesy is improved, it will improve organizational culture. Compensation has a positive and significant effect on organizational culture. If compensation is increased, which includes intrinsic compensation and extrinsic compensation, it will improve the organizational culture. Corporate Strategy, OCB and Compensation are positively and significantly related to the overall Company Performance variable through Organizational Culture.

\section{References}

Amin, M., Ismail, W. K. W., Rasid, S. Z. A., \& Selemani, R. D. A. (2014). The impact of human resource management practices on performance: Evidence from a Public University. The TQM Journal.

Ansoff, H. I. (1965). Corporate strategy: An analytic approach to business policy for growth and expansion. McGraw-Hill Companies.

Awadh, A. M., \& Alyahya, M. S. (2013). Impact of organizational culture on employee performance. International Review of Management and Business Research, 2(1), 168.

Badawy, T. E., Trujillo-Reyes, J. C., \& Magdy, M. M. (2017). Exploring the relationship between organizational culture, organizational citizenship behavior and job satisfaction: A comparative study between Egypt and Mexico. International Journal of Management and Administrative Sciences (IJMAS), 4(6), 1-15.

Banker, R. D., Darrough, M. N., Huang, R., \& Plehn-Dujowich, J. M. (2013). The relation between CEO compensation and past performance. The Accounting Review, 88(1), 1-30.

Chathoth, P. K., \& Olsen, M. D. (2007). The effect of environment risk, corporate strategy, and capital structure on firm performance: An empirical investigation of restaurant firms. International Journal of Hospitality Management, 26(3), 502-516.

Chen, Y., \& Jermias, J. (2014). Business strategy, executive compensation and firm performance. Accounting \& Finance, 54(1), 113-134.

Chun, S.-H., Hwang, H. J., \& Byun, Y.-H. (2015). Supply Chain Process and Green Business Activities: Application to Small and Medium Enterprises. Procedia-Social and Behavioral Sciences, 186, 862867.

de Villiers-Scheepers, M. J. (2012). Antecedents of strategic corporate entrepreneurship. European Business Review.

Ehsan, S., \& Kaleem, A. (2012). An empirical investigation of the relationship between CSR and financial performance: Evidence from manufacturing sector of Pakistan. Journal of Basic and Applied Scientific Research, 3, 2909-2922.

Ferdinand, A. T. (2014). Structural Equation Model Dalam Penelitian Manajemen, Aplikasi Model-Model Rumit Dalam Penelitian Untuk Skripsi [PhD Thesis]. Tesis dan Disertasi Doktor. In Seri Pustaka Kunci, edited by FE d. BU ....

Garri, M., Konstantopoulos, N., \& Bekiaris, M. (2013). Corporate strategy, corporate culture \& customer information. Procedia-Social and Behavioral Sciences, 73, 669-677.

Hair, J., Hollingsworth, C. L., Randolph, A. B., \& Chong, A. Y. L. (2017). An updated and expanded assessment of PLS-SEM in information systems research. Industrial Management \& Data Systems, 117(3), 442-458.

Hanzaee, K., \& Mirvaisi, M. (2013). A survey on impact of emotional intelligence, organizational citizenship behaviors and job satisfaction on employees' performance in Iranian hotel industry. Management Science Letters, 3(5), 1395-1402.

Hasbullah, J. (2006). Social capital: Menuju keunggulan budaya manusia Indonesia. MR-United Press.

Hassan, S. (2016). Impact of HRM practices on employee's performance. International Journal of Academic Research in Accounting, Finance and Management Sciences, 6(1), 15-22. 
Jacobs, R., Mannion, R., Davies, H. T., Harrison, S., Konteh, F., \& Walshe, K. (2013). The relationship between organizational culture and performance in acute hospitals. Social Science \& Medicine, 76, $115-125$.

Kizilos, M. A., Cummings, C., \& Cummings, T. G. (2013). How high-involvement work processes increase organization performance: The role of organizational citizenship behavior. The Journal of Applied Behavioral Science, 49(4), 413-436.

Kolade, O., \& Ogunnaike, O. (2014). Organizational citizenship behaviour, hospital corporate image and performance. Journal of Competitiveness, 6(1), 36-49.

Lee, M., \& Kim, H. (2017). Exploring the organizational culture's moderating role of effects of Corporate Social Responsibility (CSR) on firm performance: Focused on corporate contributions in Korea. Sustainability, 9(10), 1883.

Li, L., \& Roloff, M. E. (2007). Organizational culture and compensation systems: An examination of job applicants' attraction to organizations. International Journal of Organizational Analysis.

Madhani, P. M. (2014). Aligning compensation systems with organization culture. Compensation \& Benefits Review, 46(2), 103-115.

Martínez, R. N., \& Scott Tindale, R. (2015). Impact of organizational citizenship behavior on performance in women's sport teams. Journal of Applied Sport Psychology, 27(2), 200-215.

Muhtasom, A., Mus, H. A. R., Bijang, J., \& Latief, B. (2017). Influence of Servant Leadership, Organizational Citizenship Bahaviour on Organizational Culture and Employee Performance at Star Hotel in Makassar. Star, 486(206), 410.

O'Reilly III, C. A., Caldwell, D. F., Chatman, J. A., \& Doerr, B. (2014). The promise and problems of organizational culture: CEO personality, culture, and firm performance. Group \& Organization Management, 39(6), 595-625.

Pashib, M., Yaqubi, M., Seydmoharrami, I., \& Tatari, M. (2015). The relationship between organizational culture and organizational citizenship behavior among staff of Torbat Heydariyeh University of Medical Sciences in 2015. Journal of Torbat Heydariyeh University of Medical Sciences, 3(2), 36-31.

Pfeffer, J. (1998). Seven practices of successful organizations. California Management Review, 40(2), 97.

Purnama, C. (2013). Influence analysis of organizational culture organizational commitment job and satisfaction organizational citizenship behavior (OCB) toward improved organizational performance. International Journal of Business, Humanities and Technology, 3(5), 86-100.

Sadeghi, G., Ahmadi, M., \& Yazdi, M. T. (2016). The relationship between organizational citizenship behavior and organizational performance (case study: Agricultural Jihad Organization of Mazandaran Province). Problems and Perspectives in Management, 14, Iss. 3 (spec. iss.), 317-324.

Shahin, A., Naftchali, J. S., \& Pool, J. K. (2014). Developing a model for the influence of perceived organizational climate on organizational citizenship behaviour and organizational performance based on balanced score card. International Journal of Productivity and Performance Management.

Silalahi, U. (2012). Metode penelitian sosial (1st ed.). PT. Refika Aditama.

Sudaryono. (2019). Metodologi Penelitian (3rd ed.). PT. Rajagrafindo Persada.

Sugiyono. (2017). Metode Penelitian Kuantitatif, Kualitatif, Dan R\&D. CV Alfabeta.

Tasgit, Y. E., Şentürk, F. K., \& Ergün, E. (2017). Corporate Culture and Business Strategy: Which strategies can be applied more easily in which culture? International Journal of Business and Social Science, $8(6), 80-91$.

Tomczyk, D., Lee, J., \& Winslow, E. (2013). Entrepreneurs' personal values, compensation, and high growth firm performance. Journal of Small Business Management, 51(1), 66-82.

Tseng, S.-M. (2010). The correlation between organizational culture and knowledge conversion on corporate performance. Journal of Knowledge Management.

Turro Sol, A. (2015). Antecedents and consequences of corporate entrepreneurship an international study. Universitat Autònoma de Barcelona.

Uzkurt, C., Kumar, R., Kimzan, H. S., \& Sert, H. (2012). The impact of environmental uncertainty dimensions on organisational innovativeness: An empirical study on SMEs. International Journal of Innovation Management, 16(2), 1250015. 
Wernerfelt, B. (1984). A resource-based view of the firm. Strategic Management Journal, 5(2), 171-180. Zhou, Y., Fan, X., \& Son, J. (2019). How and when matter: Exploring the interaction effects of highperformance work systems, employee participation, and human capital on organizational innovation. Human Resource Management, 58(3), 253-268.

\section{Copyrights}

Copyright for this article is retained by the author(s), with first publication rights granted to the journal.

This is an open-access article distributed under the terms and conditions of the Creative Commons Attribution license (http://creativecommons.org/licenses/by/4.0/). 